\title{
Lysophospholipid (LPA) receptors in GtoPdb v.2021.2
}

\author{
Victoria Blaho $^{1}$, Jerold Chun ${ }^{1}$, Danielle Jones ${ }^{1}$, Deepa Jonnalagadda ${ }^{1}$, Yasuyuki Kihara ${ }^{1}$, Tony Ngo $^{1}$,
} Manisha Ray ${ }^{1}$ and Valerie P. Tan ${ }^{1}$

1. Sanford Burnham Prebys Medical Discovery Institute, USA

\begin{abstract}
Lysophosphatidic acid (LPA) receptors (nomenclature as agreed by the NC-IUPHAR Subcommittee on Lysophospholipid Receptors $[55,19,82,129]$ ) are activated by the endogenous phospholipid LPA. The first receptor, $\mathrm{LPA}_{1}$, was identified as ventricular zone gene-1 (vzg-1) [40], This discovery represented the beginning of the de-orphanisation of members of the endothelial differentiation gene (edg) family, as other LPA and sphingosine 1-phosphate (S1P) receptors were found. Five additional LPA receptors $\left(\mathrm{LPA}_{2,3,4,5,6}\right)$ have since been identified [82] and their gene nomenclature codified for human LPAR1, LPAR2, etc. (HUGO Gene Nomenclature Committee, HGNC) and Lpar1, Lpar2, etc. for mice (Mouse Genome Informatics Database, MGI) to reflect species and receptor function of their corresponding proteins. The crystal structure of LPA1 is solved and indicates that LPA accesses the extracellular binding pocket, consistent with its proposed delivery via autotaxin [13]. These studies have also implicated cross-talk with endocannabinoids via phosphorylated intermediates that can also activate these receptors. The binding affinities to $\mathrm{LPA}_{1}$ of unlabeled, natural LPA and anandamide phosphate (AEAp) were measured using backscattering interferometry $\left(\mathrm{pK}_{\mathrm{d}}=9\right)[83,104]$. Utilization of this method indicated affinities that were 77-fold lower than when measured using radioactivity-based protocols [128]. Targeted deletion of LPA receptors has clarified signalling pathways and identified physiological and pathophysiological roles. Multiple groups have independently published validation of all six LPA receptors described in these tables, and further validation was achieved using a distinct read-out via a novel TGF $\alpha$ "shedding* assay [48]. LPA LPA has been proposed to be a ligand for GPCR35 [94], supported by a recent study revealing that LPA modulates macrophage function through GPR35 [54]. However chemokine (C-X-C motif) ligand 17 (CXCL17) is reported to be a ligand for GPR35/CXCR8 [76]. Moreover, LPA has also been described as an agonist for the transient receptor potential (Trp) ion channels TRPV1 [87] and TRPA1 [58]. All of these proposed non-GPCR receptor identities require confirmation and are not currently recognized as bona fide LPA receptors.
\end{abstract}

\section{Contents}

This is a citation summary for Lysophospholipid (LPA) receptors in the Guide to Pharmacology database (GtoPdb). It exists purely as an adjunct to the database to facilitate the recognition of citations to and from the database by citation analyzers. Readers will almost certainly want to visit the relevant sections of the database which are given here under database links.

GtoPdb is an expert-driven guide to pharmacological targets and the substances that act on them. GtoPdb is a reference work which is most usefully represented as an on-line database. As in any publication this work should be appropriately cited, and the papers it cites should also be recognized. This document provides a citation for the relevant parts of the database, and also provides a reference list for the research cited by those parts. For further details see [11].

Please note that the database version for the citations given in GtoPdb are to the most recent preceding version in which the family or its subfamilies and targets were substantially changed. The links below are to the current version. If you need to consult the cited version, rather than the most recent version, please contact the GtoPdb curators.

\section{Database links}

Lysophospholipid (LPA) receptors 
https://www.guidetopharmacology.org/GRAC/FamilyDisplayForward?familyId=36

Introduction to Lysophospholipid (LPA) receptors

https://www.guidetopharmacology.org/GRAC/FamilyIntroductionForward?familyId=36

Receptors
$\mathrm{LPA}_{1}$ receptor
https://www.guidetopharmacology.org/GRAC/ObjectDisplayForward?objectId=272
$\mathrm{LPA}_{2}$ receptor
https://www.guidetopharmacology.org/GRAC/ObjectDisplayForward?objectId=273
$\mathrm{LPA}_{3}$ receptor
https://www.guidetopharmacology.org/GRAC/ObjectDisplayForward?objectId=274
$\mathrm{LPA}_{4}$ receptor
https://www.guidetopharmacology.org/GRAC/ObjectDisplayForward?objectId=94
$\mathrm{LPA}_{5}$ receptor
https://www.guidetopharmacology.org/GRAC/ObjectDisplayForward?objectId=124
$\mathrm{LPA}_{6}$ receptor
https://www.guidetopharmacology.org/GRAC/ObjectDisplayForward?objectId=163

\section{References}

1. Aikawa S, Kano K, Inoue A and Aoki J. (2017) Proliferation of mouse endometrial stromal cells in culture is highly sensitive to lysophosphatidic acid signaling. Biochem Biophys Res Commun 484: 202-208 [PMID:28073697]

2. Allard J, Barrón S, Diaz J, Lubetzki C, Zalc B, Schwartz JC and Sokoloff P. (1998) A rat G proteincoupled receptor selectively expressed in myelin-forming cells. Eur J Neurosci 10: 1045-53 [PMID:9753172]

3. Amisten S, Braun OO, Bengtsson A and Erlinge D. (2008) Gene expression profiling for the identification of G-protein coupled receptors in human platelets. Thromb Res 122: 47-57 [PMID:17920662]

4. An S, Bleu T, Hallmark OG and Goetzl EJ. (1998) Characterization of a novel subtype of human G protein-coupled receptor for lysophosphatidic acid. J Biol Chem 273: 7906-10 [PMID:9525886]

5. Azeem Z, Jelani M, Naz G, Tariq M, Wasif N, Kamran-Ul-Hassan Naqvi S, Ayub M, Yasinzai M, Amin-Ud-Din M and Wali A et al.. (2008) Novel mutations in G protein-coupled receptor gene (P2RY5) in families with autosomal recessive hypotrichosis (LAH3). Hum Genet 123: 515-9 [PMID:18461368]

6. Azhar A, Tariq M, Baig SM, Dahl N and Klar J. (2012) A novel mutation in lysophosphatidic acid receptor 6 gene in autosomal recessive hypotrichosis and evidence for a founder effect. Eur J Dermatol 22: 464-6 [PMID:22531990]

7. Balogh A, Shimizu Y, Lee SC, Norman DD, Gangwar R, Bavaria M, Moon C, Shukla P, Rao R and Ray R et al.. (2015) The autotaxin-LPA2 GPCR axis is modulated by $\gamma$-irradiation and facilitates DNA damage repair. Cell Signal 27: 1751-62 [PMID:26027517]

8. Bandoh K, Aoki J, Hosono H, Kobayashi S, Kobayashi T, Murakami-Murofushi K, Tsujimoto M, Arai H and Inoue K. (1999) Molecular cloning and characterization of a novel human G-proteincoupled receptor, EDG7, for lysophosphatidic acid. J Biol Chem 274: 27776-85 [PMID:10488122]

9. Bandoh K, Aoki J, Taira A, Tsujimoto M, Arai H and Inoue K. (2000) Lysophosphatidic acid (LPA) receptors of the EDG family are differentially activated by LPA species. Structure-activity relationship of cloned LPA receptors. FEBS Lett 478: 159-65 [PMID:10922489]

10. Beck HP, Kohn T, Rubenstein S, Hedberg C, Schwandner R, Hasslinger K, Dai K, Li C, Liang L and Wesche $\mathrm{H}$ et al.. (2008) Discovery of potent LPA2 (EDG4) antagonists as potential anticancer agents. Bioorg Med Chem Lett 18: 1037-41 [PMID:18178086]

11. Buneman P, Christie G, Davies JA, Dimitrellou R, Harding SD, Pawson AJ, Sharman JL and Wu Y. (2020) Why data citation isn't working, and what to do about it Database 2020 [PMID:32367113]

12. Choi JW, Herr DR, Noguchi K, Yung YC, Lee CW, Mutoh T, Lin ME, Teo ST, Park KE, Mosley AN and Chun J. (2010) LPA receptors: subtypes and biological actions. Annu Rev Pharmacol Toxicol 50: 157-86 [PMID:20055701]

13. Chrencik JE, Roth CB, Terakado M, Kurata H, Omi R, Kihara Y, Warshaviak D, Nakade S, AsmarRovira G and Mileni M et al.. (2015) Crystal Structure of Antagonist Bound Human Lysophosphatidic Acid Receptor 1. Cell 161: 1633-43 [PMID:26091040]

14. Chun J, Hla T, Lynch KR, Spiegel S and Moolenaar WH. (2010) International Union of Basic and Clinical Pharmacology. LXXVIII. Lysophospholipid receptor nomenclature. Pharmacol Rev 62 : 579-87 [PMID:21079037]

15. Contos JJ and Chun J. (1998) Complete cDNA sequence, genomic structure, and chromosomal 
localization of the LPA receptor gene, lpA1/vzg-1/Gpcr26. Genomics 51: 364-78 [PMID:9721207]

16. Contos JJ and Chun J. (2000) Genomic characterization of the lysophosphatidic acid receptor gene, $\operatorname{lp}(\mathrm{A} 2) / \mathrm{Edg} 4$, and identification of a frameshift mutation in a previously characterized cDNA. Genomics 64: 155-69 [PMID:10729222]

17. Contos JJ, Fukushima N, Weiner JA, Kaushal D and Chun J. (2000) Requirement for the lpA1 lysophosphatidic acid receptor gene in normal suckling behavior. Proc Natl Acad Sci USA 97: 13384-9 [PMID:11087877]

18. Dancs PT, Ruisanchez É, Balogh A, Panta CR, Miklós Z, Nüsing RM, Aoki J, Chun J, Offermanns $S$ and Tigyi $G$ et al.. (2017) $\mathrm{LPA}_{1}$ receptor-mediated thromboxane $\mathrm{A}_{2}$ release is responsible for lysophosphatidic acid-induced vascular smooth muscle contraction. FASEB J 31: 1547-1555 [PMID:28069828]

19. Davenport AP, Alexander SP, Sharman JL, Pawson AJ, Benson HE, Monaghan AE, Liew WC, Mpamhanga CP, Bonner TI and Neubig RR et al.. (2013) International Union of Basic and Clinical Pharmacology. LXXXVIII. G protein-coupled receptor list: recommendations for new pairings with cognate ligands. Pharmacol Rev 65: 967-86 [PMID:23686350]

20. Diao H, Aplin JD, Xiao S, Chun J, Li Z, Chen S and Ye X. (2011) Altered spatiotemporal expression of collagen types I, III, IV, and VI in Lpar3-deficient peri-implantation mouse uterus. Biol Reprod 84: 255-65 [PMID:20864640]

21. Diez-Roux G, Banfi S, Sultan M, Geffers L, Anand S, Rozado D, Magen A, Canidio E, Pagani M and Peluso I et al.. (2011) A high-resolution anatomical atlas of the transcriptome in the mouse embryo. PLoS Biol 9: e1000582 [PMID:21267068]

22. Dubin AE, Bahnson T, Weiner JA, Fukushima N and Chun J. (1999) Lysophosphatidic acid stimulates neurotransmitter-like conductance changes that precede GABA and L-glutamate in early, presumptive cortical neuroblasts. J Neurosci 19: 1371-81 [PMID:9952414]

23. Dubin AE, Herr DR and Chun J. (2010) Diversity of lysophosphatidic acid receptor-mediated intracellular calcium signaling in early cortical neurogenesis. J Neurosci 30: 7300-9 [PMID:20505096]

24. Durgam GG, Virag T, Walker MD, Tsukahara R, Yasuda S, Liliom K, van Meeteren LA, Moolenaar WH, Wilke N and Siess W et al.. (2005) Synthesis, structure-activity relationships, and biological evaluation of fatty alcohol phosphates as lysophosphatidic acid receptor ligands, activators of PPARgamma, and inhibitors of autotaxin. J Med Chem 48: 4919-30 [PMID:16033271]

25. Estivill-Torrús G, Llebrez-Zayas P, Matas-Rico E, Santín L, Pedraza C, De Diego I, Del Arco I, Fernández-Llebrez P, Chun J and De Fonseca FR. (2008) Absence of LPA1 signaling results in defective cortical development. Cereb Cortex 18: 938-50 [PMID:17656621]

26. Fells JI, Tsukahara R, Fujiwara Y, Liu J, Perygin DH, Osborne DA, Tigyi G and Parrill AL. (2008) Identification of non-lipid LPA3 antagonists by virtual screening. Bioorg Med Chem 16: 6207-17 [PMID:18467108]

27. Fells JI, Tsukahara R, Liu J, Tigyi G and Parrill AL. (2009) Structure-based drug design identifies novel LPA3 antagonists. Bioorg Med Chem 17: 7457-64 [PMID:19800804]

28. Fischer DJ, Nusser N, Virag T, Yokoyama K, Wang Da, Baker DL, Bautista D, Parrill AL and Tigyi G. (2001) Short-chain phosphatidates are subtype-selective antagonists of lysophosphatidic acid receptors. Mol Pharmacol 60: 776-84 [PMID:11562440]

29. Fukushima N, Ishii I, Habara Y, Allen CB and Chun J. (2002) Dual regulation of actin rearrangement through lysophosphatidic acid receptor in neuroblast cell lines: actin depolymerization by $\mathrm{Ca}(2+)$-alpha-actinin and polymerization by rho. Mol Biol Cell 13: 2692-705 [PMID:12181339]

30. Fukushima N, Kimura Y and Chun J. (1998) A single receptor encoded by vzg-1/lpA1/edg-2 couples to $\mathrm{G}$ proteins and mediates multiple cellular responses to lysophosphatidic acid. Proc Natl Acad Sci USA 95: 6151-6 [PMID:9600933]

31. Fukushima N, Shano S, Moriyama R and Chun J. (2007) Lysophosphatidic acid stimulates neuronal differentiation of cortical neuroblasts through the LPA1-G(i/o) pathway. Neurochem Int 50: 302-7 [PMID:17056154]

32. Fukushima N, Weiner JA and Chun J. (2000) Lysophosphatidic acid (LPA) is a novel extracellular regulator of cortical neuroblast morphology. Dev Biol 228: 6-18 [PMID:11087622]

33. Fukushima N, Weiner JA, Kaushal D, Contos JJ, Rehen SK, Kingsbury MA, Kim KY and Chun J. (2002) Lysophosphatidic acid influences the morphology and motility of young, postmitotic cortical neurons. Mol Cell Neurosci 20: 271-82 [PMID:12093159]

34. González-Gil I, Zian D, Vázquez-Villa H, Hernández-Torres G, Martínez RF, Khiar-Fernández N, Rivera R, Kihara Y, Devesa I and Mathivanan S et al.. (2020) A Novel Agonist of the Type 1 Lysophosphatidic Acid Receptor (LPA 1 ), UCM-05194, Shows Efficacy in Neuropathic Pain Amelioration. J Med Chem 63: 2372-2390 [PMID:31790581]

35. Guillot E, Le Bail JC, Paul P, Fourgous V, Briand P, Partiseti M, Cornet B, Janiak P and Philippo C. (2020) Lysophosphatidic Acid Receptor Agonism: Discovery of Potent Nonlipid Benzofuran Ethanolamine Structures. J Pharmacol Exp Ther 374: 283-294 [PMID:32409422] 
36. Hama K, Aoki J, Inoue A, Endo T, Amano T, Motoki R, Kanai M, Ye X, Chun J and Matsuki N et al.. (2007) Embryo spacing and implantation timing are differentially regulated by LPA3mediated lysophosphatidic acid signaling in mice. Biol Reprod 77: 954-9 [PMID:17823089]

37. Hasegawa Y, Erickson JR, Goddard GJ, Yu S, Liu S, Cheng KW, Eder A, Bandoh K, Aoki J and Jarosz R et al.. (2003) Identification of a phosphothionate analogue of lysophosphatidic acid (LPA) as a selective agonist of the LPA3 receptor. J Biol Chem 278: 11962-9 [PMID:12554733]

38. Hata E, Sasaki N, Takeda A, Tohya K, Umemoto E, Akahoshi N, Ishii S, Bando K, Abe T and Kano K et al.. (2016) Lysophosphatidic acid receptors LPA4 and LPA6 differentially promote lymphocyte transmigration across high endothelial venules in lymph nodes. Int Immunol 28: 283-92 [PMID:26714589]

39. Heasley BH, Jarosz R, Lynch KR and Macdonald TL. (2004) Initial structure-activity relationships of lysophosphatidic acid receptor antagonists: discovery of a high-affinity LPA1/LPA3 receptor antagonist. Bioorg Med Chem Lett 14: 2735-40 [PMID:15125924]

40. Hecht JH, Weiner JA, Post SR and Chun J. (1996) Ventricular zone gene-1 (vzg-1) encodes a lysophosphatidic acid receptor expressed in neurogenic regions of the developing cerebral cortex. J Cell Biol 135: 1071-83 [PMID:8922387]

41. Heise CE, Santos WL, Schreihofer AM, Heasley BH, Mukhin YV, Macdonald TL and Lynch KR. (2001) Activity of 2-substituted lysophosphatidic acid (LPA) analogs at LPA receptors: discovery of a LPA1/LPA3 receptor antagonist. Mol Pharmacol 60: 1173-80 [PMID:11723223]

42. Herr KJ, Herr DR, Lee CW, Noguchi K and Chun J. (2011) Stereotyped fetal brain disorganization is induced by hypoxia and requires lysophosphatidic acid receptor 1 (LPA1) signaling. Proc Natl Acad Sci USA 108: 15444-9 [PMID:21878565]

43. Horev L, Saad-Edin B, Ingber A and Zlotogorski A. (2010) A novel deletion mutation in P2RY5/LPA(6) gene cause autosomal recessive woolly hair with hypotrichosis. J Eur Acad Dermatol Venereol 24: 858-9 [PMID:20015179]

44. Hu J, Oda SK, Shotts K, Donovan EE, Strauch P, Pujanauski LM, Victorino F, Al-Shami A, Fujiwara Y and Tigyi G et al.. (2014) Lysophosphatidic acid receptor 5 inhibits B cell antigen receptor signaling and antibody response. J Immunol 193: 85-95 [PMID:24890721]

45. Igarashi H, Akahoshi N, Ohto-Nakanishi T, Yasuda D and Ishii S. (2015) The lysophosphatidic acid receptor LPA4 regulates hematopoiesis-supporting activity of bone marrow stromal cells. Sci Rep 5: 11410 [PMID:26090649]

46. Im DS. (2010) Pharmacological tools for lysophospholipid GPCRs: development of agonists and antagonists for LPA and S1P receptors. Acta Pharmacol Sin 31: 1213-22 [PMID:20729877]

47. Im DS, Heise CE, Harding MA, George SR, O'Dowd BF, Theodorescu D and Lynch KR. (2000) Molecular cloning and characterization of a lysophosphatidic acid receptor, Edg-7, expressed in prostate. Mol Pharmacol 57: 753-9 [PMID:10727522]

48. Inoue A, Ishiguro J, Kitamura H, Arima N, Okutani M, Shuto A, Higashiyama S, Ohwada T, Arai $\mathrm{H}$ and Makide K et al.. (2012) TGF $\alpha$ shedding assay: an accurate and versatile method for detecting GPCR activation. Nat Methods 9: 1021-9 [PMID:22983457]

49. Ishii I, Contos JJ, Fukushima N and Chun J. (2000) Functional comparisons of the lysophosphatidic acid receptors, LP(A1)/VZG-1/EDG-2, LP(A2)/EDG-4, and LP(A3)/EDG-7 in neuronal cell lines using a retrovirus expression system. Mol Pharmacol 58: 895-902 [PMID:11040035]

50. Jongsma M, Matas-Rico E, Rzadkowski A, Jalink K and Moolenaar WH. (2011) LPA is a chemorepellent for B16 melanoma cells: action through the cAMP-elevating LPA5 receptor. PLoS ONE 6: e29260 [PMID:22195035]

51. Kano K, Arima N, Ohgami M and Aoki J. (2008) LPA and its analogs-attractive tools for elucidation of LPA biology and drug development. Curr Med Chem 15: 2122-31 [PMID:18781939]

52. Kano K, Matsumoto H, Inoue A, Yukiura H, Kanai M, Chun J, Ishii S, Shimizu T and Aoki J. (2019) Molecular mechanism of lysophosphatidic acid-induced hypertensive response. Sci Rep 9: 2662 [PMID:30804442]

53. Kawamoto Y, Seo R, Murai N, Hiyama H and Oka H. (2018) Identification of potent lysophosphatidic acid receptor 5 (LPA5) antagonists as potential analgesic agents. Bioorg Med Chem 26: 257-265 [PMID:29208511]

54. Kaya B, Doñas C, Wuggenig P, Diaz OE, Morales RA, Melhem H, Swiss IBD. Cohort Investigators, Hernández PP, Kaymak T and Das S et al.. (2020) Lysophosphatidic AcidMediated GPR35 Signaling in CX3CR1 ${ }^{+}$Macrophages Regulates Intestinal Homeostasis. Cell Rep 32: 107979 [PMID:32755573]

55. Kihara Y, Maceyka M, Spiegel S and Chun J. (2014) Lysophospholipid receptor nomenclature review: IUPHAR Review 8. Br J Pharmacol 171: 3575-94 [PMID:24602016]

56. Kingsbury MA, Rehen SK, Contos JJ, Higgins CM and Chun J. (2003) Non-proliferative effects of lysophosphatidic acid enhance cortical growth and folding. Nat Neurosci 6: 1292-9 [PMID:14625558]

57. Kiss GN, Fells JI, Gupte R, Lee SC, Liu J, Nusser N, Lim KG, Ray RM, Lin FT and Parrill AL et al.. 
(2012) Virtual screening for LPA2-specific agonists identifies a nonlipid compound with antiapoptotic actions. Mol Pharmacol 82: 1162-73 [PMID:22968304]

58. Kittaka H, Uchida K, Fukuta N and Tominaga M. (2017) Lysophosphatidic acid-induced itch is mediated by signalling of $\mathrm{LPA}_{5}$ receptor, phospholipase D and TRPA1/TRPV1.J Physiol (Lond.) 595: 2681-2698 [PMID:28176353]

59. Kotarsky K, Boketoft A, Bristulf J, Nilsson NE, Norberg A, Hansson S, Owman C, Sillard R, LeebLundberg LM and Olde B. (2006) Lysophosphatidic acid binds to and activates GPR92, a G protein-coupled receptor highly expressed in gastrointestinal lymphocytes. J Pharmacol Exp Ther 318: 619-28 [PMID:16651401]

60. Kozian DH, Evers A, Florian P, Wonerow P, Joho S and Nazare M. (2012) Selective non-lipid modulator of LPA5 activity in human platelets. Bioorg Med Chem Lett 22: 5239-43 [PMID:22801643]

61. Kritikou E, van Puijvelde GH, van der Heijden T, van Santbrink PJ, Swart M, Schaftenaar FH, Kröner MJ, Kuiper J and Bot I. (2016) Inhibition of lysophosphatidic acid receptors 1 and 3 attenuates atherosclerosis development in LDL-receptor deficient mice. Sci Rep 6: 37585 [PMID:27883026]

62. Kuo B, Szabó E, Lee SC, Balogh A, Norman D, Inoue A, Ono Y, Aoki J and Tigyi G. (2018) The $\mathrm{LPA}_{2}$ receptor agonist Radioprotectin-1 spares Lgr5-positive intestinal stem cells from radiation injury in murine enteroids. Cell Signal 51: 23-33 [PMID:30063964]

63. Ledein L, Léger B, Dees C, Beyer C, Distler A, Vettori S, Boukaiba R, Bidouard JP, Schaefer M and Pernerstorfer J et al.. (2020) Translational engagement of lysophosphatidic acid receptor 1 in skin fibrosis: from dermal fibroblasts of patients with scleroderma to tight skin 1 mouse. $B r J$ Pharmacol 177: 4296-4309 [PMID:32627178]

64. Lee CW, Rivera R, Dubin AE and Chun J. (2007) LPA(4)/GPR23 is a lysophosphatidic acid (LPA) receptor utilizing G(s)-, G(q)/G(i)-mediated calcium signaling and G(12/13)-mediated Rho activation. J Biol Chem 282: 4310-7 [PMID:17166850]

65. Lee CW, Rivera R, Gardell S, Dubin AE and Chun J. (2006) GPR92 as a new G12/13- and Gqcoupled lysophosphatidic acid receptor that increases cAMP, LPA5. J Biol Chem 281: 23589-97 [PMID:16774927]

66. Lee M, Choi S, Halldén G, Yo SJ, Schichnes D and Aponte GW. (2009) P2Y5 is a G(alpha)i, G(alpha)12/13 G protein-coupled receptor activated by lysophosphatidic acid that reduces intestinal cell adhesion. Am J Physiol Gastrointest Liver Physiol 297: G641-54 [PMID:19679818]

67. Lee Z, Cheng CT, Zhang H, Subler MA, Wu J, Mukherjee A, Windle JJ, Chen CK and Fang X. (2008) Role of LPA4/p2y9/GPR23 in negative regulation of cell motility. Mol Biol Cell 19: 543545 [PMID:18843048]

68. Li Q, Schachter JB, Harden TK and Nicholas RA. (1997) The 6H1 orphan receptor, claimed to be the p2y5 receptor, does not mediate nucleotide-promoted second messenger responses. Biochem Biophys Res Commun 236: 455-60 [PMID:9240460]

69. Liliom K, Tsukahara T, Tsukahara R, Zelman-Femiak M, Swiezewska E and Tigyi G. (2006) Farnesyl phosphates are endogenous ligands of lysophosphatidic acid receptors: inhibition of LPA GPCR and activation of PPARs. Biochim Biophys Acta 1761: 1506-14 [PMID:17092771]

70. Lin ME, Rivera RR and Chun J. (2012) Targeted deletion of LPA5 identifies novel roles for lysophosphatidic acid signaling in development of neuropathic pain. J Biol Chem 287: 17608-17 [PMID:22461625]

71. Lin S, Yeruva S, He P, Singh AK, Zhang H, Chen M, Lamprecht G, de Jonge HR, Tse M, Donowitz M, Hogema BM, Chun J, Seidler U and Yun CC. (2010) Lysophosphatidic acid stimulates the intestinal brush border $\mathrm{Na}(+) / \mathrm{H}(+)$ exchanger 3 and fluid absorption via LPA(5) and NHERF2. Gastroenterology 138: 649-58 [PMID:19800338]

72. Lu Y, Wang Z, Li CM, Chen J, Dalton JT, Li W and Miller DD. (2010) Synthesis, in vitro structureactivity relationship, and in vivo studies of 2-arylthiazolidine-4-carboxylic acid amides as anticancer agents. Bioorg Med Chem 18: 477-95 [PMID:20056548]

73. Lummis NC, Sánchez-Pavón P, Kennedy G, Frantz AJ, Kihara Y, Blaho VA and Chun J. (2019) $\mathrm{LPA}_{1 / 3}$ overactivation induces neonatal posthemorrhagic hydrocephalus through ependymal loss and ciliary dysfunction. Sci Adv 5: eaax2011 [PMID:31633020]

74. Lundequist A and Boyce JA. (2011) LPA5 is abundantly expressed by human mast cells and important for lysophosphatidic acid induced MIP-1ß release. PLOS ONE 6: e18192 [PMID:21464938]

75. Mahmoudi H, Tug E, Parlak AH, Atasoy HI, Ludwig M, Polat M, Pasternack SM and Betz RC. (2012) Identification of an Alu-mediated 12.2-kb deletion of the complete LPAR6 (P2RY5) gene in a Turkish family with hypotrichosis and woolly hair. Exp Dermatol 21: 469-71 [PMID:22621192]

76. Maravillas-Montero JL, Burkhardt AM, Hevezi PA, Carnevale CD, Smit MJ and Zlotnik A. (2015) Cutting edge: GPR35/CXCR8 is the receptor of the mucosal chemokine CXCL17. J Immunol 194: 29-33 [PMID:25411203]

77. Masago K, Kihara Y, Yanagida K, Hamano F, Nakagawa S, Niwa M and Shimizu T. (2018) 
Lysophosphatidic acid receptor, $\mathrm{LPA}_{6}$, regulates endothelial blood-brain barrier function: Implication for hepatic encephalopathy. Biochem Biophys Res Commun 501: 1048-1054 [PMID:29778535]

78. Matas-Rico E, García-Diaz B, Llebrez-Zayas P, López-Barroso D, Santín L, Pedraza C, SmithFernández A, Fernández-Llebrez P, Tellez T and Redondo M et al.. (2008) Deletion of lysophosphatidic acid receptor LPA1 reduces neurogenesis in the mouse dentate gyrus. Mol Cell Neurosci 39: 342-55 [PMID:18708146]

79. Mathew D, Kremer KN, Strauch P, Tigyi G, Pelanda R and Torres RM. (2019) LPA 5 Is an Inhibitory Receptor That Suppresses CD8 T-Cell Cytotoxic Function via Disruption of Early TCR Signaling. Front Immunol 10: 1159 [PMID:31231367]

80. McGiffert C, Contos JJ, Friedman B and Chun J. (2002) Embryonic brain expression analysis of lysophospholipid receptor genes suggests roles for $\mathrm{s} 1 \mathrm{p}(1)$ in neurogenesis and $\mathrm{s} 1 \mathrm{p}(1-3)$ in angiogenesis. FEBS Lett 531: 103-8 [PMID:12401212]

81. Mirendil H, Thomas EA, De Loera C, Okada K, Inomata Y and Chun J. (2015) LPA signaling initiates schizophrenia-like brain and behavioral changes in a mouse model of prenatal brain hemorrhage. Transl Psychiatry 5: e541 [PMID:25849980]

82. Mizuno H and Kihara Y. (2020) Druggable Lipid GPCRs: Past, Present, and Prospects. Adv Exp Med Biol 1274: 223-258 [PMID:32894513]

83. Mizuno H, Kihara Y, Kussrow A, Chen A, Ray M, Rivera R, Bornhop DJ and Chun J. (2019) Lysophospholipid G protein-coupled receptor binding parameters as determined by backscattering interferometry. J Lipid Res 60: 212-217 [PMID:30463988]

84. Mukherjee A, Ma Y, Yuan F, Gong Y, Fang Z, Mohamed EM, Berrios E, Shao H and Fang X. (2015) Lysophosphatidic Acid Up-Regulates Hexokinase II and Glycolysis to Promote Proliferation of Ovarian Cancer Cells. Neoplasia 17: 723-34 [PMID:26476080]

85. Murai N, Hiyama H, Kiso T, Sekizawa T, Watabiki T, Oka H and Aoki T. (2017) Analgesic effects of novel lysophosphatidic acid receptor 5 antagonist AS2717638 in rodents. Neuropharmacology 126: 97-107 [PMID:28859883]

86. Nakamura M and Tokura Y. (2009) Congenital woolly hair without P2RY5 mutation. Dermatoendocrinol 1: 58-9 [PMID:20046591]

87. Nieto-Posadas A, Picazo-Juárez G, Llorente I, Jara-Oseguera A, Morales-Lázaro S, EscalanteAlcalde D, Islas LD and Rosenbaum T. (2012) Lysophosphatidic acid directly activates TRPV1 through a C-terminal binding site. Nat Chem Biol 8: 78-85 [PMID:22101604]

88. Noguchi K, Ishii S and Shimizu T. (2003) Identification of p2y9/GPR23 as a novel G proteincoupled receptor for lysophosphatidic acid, structurally distant from the Edg family. J Biol Chem 278: 25600-6 [PMID:12724320]

89. Oda SK, Strauch P, Fujiwara Y, Al-Shami A, Oravecz T, Tigyi G, Pelanda R and Torres RM. (2013) Lysophosphatidic acid inhibits CD8 T cell activation and control of tumor progression. Cancer Immunol Res 1: 245-55 [PMID:24455753]

90. Oh DY, Yoon JM, Moon MJ, Hwang JI, Choe H, Lee JY, Kim JI, Kim S, Rhim H, O'Dell DK, Walker JM, Na HS, Lee MG, Kwon HB, Kim K and Seong JY. (2008) Identification of farnesyl pyrophosphate and N-arachidonylglycine as endogenous ligands for GPR92. J Biol Chem 283: 21054-64 [PMID:18499677]

91. Ohashi T and Yamamoto T. (2015) Antifibrotic effect of lysophosphatidic acid receptors LPA1 and LPA3 antagonist on experimental murine scleroderma induced by bleomycin. Exp Dermatol 24: 698-702 [PMID:25959255]

92. Ohta H, Sato K, Murata N, Damirin A, Malchinkhuu E, Kon J, Kimura T, Tobo M, Yamazaki Y, Watanabe T, Yagi M, Sato M, Suzuki R, Murooka H, Sakai T, Nishitoba T, Im DS, Nochi H, Tamoto K, Tomura H and Okajima F. (2003) Ki16425, a subtype-selective antagonist for EDGfamily lysophosphatidic acid receptors. Mol Pharmacol 64: 994-1005 [PMID:14500756]

93. Ohuchi H, Hamada A, Matsuda H, Takagi A, Tanaka M, Aoki J, Arai H and Noji S. (2008) Expression patterns of the lysophospholipid receptor genes during mouse early development. Dev Dyn 237: 3280-94 [PMID:18924241]

94. Oka S, Ota R, Shima M, Yamashita A and Sugiura T. (2010) GPR35 is a novel lysophosphatidic acid receptor. Biochem Biophys Res Commun 395: 232-7 [PMID:20361937]

95. Okusa MD, Ye H, Huang L, Sigismund L, Macdonald T and Lynch KR. (2003) Selective blockade of lysophosphatidic acid LPA3 receptors reduces murine renal ischemia-reperfusion injury. Am J Physiol Renal Physiol 285: F565-74 [PMID:12770838]

96. Olianas MC, Dedoni S and Onali P. (2020) Antidepressants induce profibrotic responses via the lysophosphatidic acid receptor LPA 1 . Eur J Pharmacol 873: 172963 [PMID:32007501]

97. Pasternack SM, Murugusundram S, Eigelshoven S, Müller M, Kruse R, Lehmann P and Betz RC. (2009) Novel mutations in the P2RY5 gene in one Turkish and two Indian patients presenting with hypotrichosis and woolly hair. Arch Dermatol Res 301: 621-4 [PMID:19529952]

98. Pasternack SM, von Kügelgen I, Aboud KA, Lee YA, Rüschendorf F, Voss K, Hillmer AM, Molderings GJ, Franz T, Ramirez A, Nürnberg P, Nöthen MM and Betz RC. (2008) G proteincoupled receptor P2Y5 and its ligand LPA are involved in maintenance of human hair growth. 
Nat Genet 40: 329-34 [PMID:18297070]

99. Pasternack SM, von Kügelgen I, Müller M, Oji V, Traupe H, Sprecher E, Nöthen MM, Janecke AR and Betz RC. (2009) In vitro analysis of LIPH mutations causing hypotrichosis simplex: evidence confirming the role of lipase $\mathrm{H}$ and lysophosphatidic acid in hair growth. $J$ Invest Dermatol 129: 2772-6 [PMID:19536142]

100. Pedraza C, Sánchez-López J, Castilla-Ortega E, Rosell-Valle C, Zambrana-Infantes E, GarcíaFernández M, Rodriguez de Fonseca F, Chun J, Santín LJ and Estivill-Torrús G. (2014) Fear extinction and acute stress reactivity reveal a role of LPA(1) receptor in regulating emotionallike behaviors. Brain Struct Funct 219: 1659-72 [PMID:23775489]

101. Petukhova L, Sousa Jr EC, Martinez-Mir A, Vitebsky A, Dos Santos LG, Shapiro L, Haynes C, Gordon D, Shimomura Y and Christiano AM. (2008) Genome-wide linkage analysis of an autosomal recessive hypotrichosis identifies a novel P2RY5 mutation. Genomics 92: 273-8 [PMID:18692127]

102. Plastira I, Bernhart E, Goeritzer M, Reicher H, Kumble VB, Kogelnik N, Wintersperger A, Hammer A, Schlager S and Jandl K et al.. (2016) 1-Oleyl-lysophosphatidic acid (LPA) promotes polarization of BV-2 and primary murine microglia towards an M1-like phenotype. $J$ Neuroinflammation 13: 205 [PMID:27565558]

103. Qian L, Xu Y, Simper T, Jiang G, Aoki J, Umezu-Goto M, Arai H, Yu S, Mills GB and Tsukahara R et al.. (2006) Phosphorothioate analogues of alkyl lysophosphatidic acid as LPA3 receptorselective agonists. ChemMedChem 1: 376-83 [PMID:16892372]

104. Ray M, Nagai K, Kihara Y, Kussrow A, Kammer MN, Frantz A, Bornhop DJ and Chun J. (2020) Unlabeled lysophosphatidic acid receptor binding in free solution as determined by a compensated interferometric reader. J Lipid Res 61: 1244-1251 [PMID:32513900]

105. Rivera RR, Lin ME, Bornhop EC and Chun J. (2020) Conditional Lpar1 gene targeting identifies cell types mediating neuropathic pain. FASEB J 34: 8833-8842 [PMID:32929779]

106. Santos WL, Heasley BH, Jarosz R, Carter KM, Lynch KR and Macdonald TL. (2004) Synthesis and biological evaluation of phosphonic and thiophosphoric acid derivatives of lysophosphatidic acid. Bioorg Med Chem Lett 14: 3473-6 [PMID:15177455]

107. Sattikar A, Dowling MR and Rosethorne EM. (2017) Endogenous lysophosphatidic acid (LPA1 ) receptor agonists demonstrate ligand bias between calcium and ERK signalling pathways in human lung fibroblasts. Br J Pharmacol 174: 227-237 [PMID:27864940]

108. Schmitz K, Brunkhorst R, de Bruin N, Mayer CA, Häussler A, Ferreiros N, Schiffmann S, Parnham MJ, Tunaru S and Chun J et al.. (2017) Dysregulation of lysophosphatidic acids in multiple sclerosis and autoimmune encephalomyelitis. Acta Neuropathol Commun 5: 42 [PMID:28578681]

109. Shimomura Y, Garzon MC, Kristal L, Shapiro L and Christiano AM. (2009) Autosomal recessive woolly hair with hypotrichosis caused by a novel homozygous mutation in the P2RY5 gene. Exp Dermatol 18: 218-21 [PMID:18803659]

110. Shimomura Y, Wajid M, Ishii Y, Shapiro L, Petukhova L, Gordon D and Christiano AM. (2008) Disruption of P2RY5, an orphan G protein-coupled receptor, underlies autosomal recessive woolly hair. Nat Genet 40: 335-9 [PMID:18297072]

111. Simon MF, Daviaud D, Pradère JP, Grès S, Guigné C, Wabitsch M, Chun J, Valet P and SaulnierBlache JS. (2005) Lysophosphatidic acid inhibits adipocyte differentiation via lysophosphatidic acid 1 receptor-dependent down-regulation of peroxisome proliferator-activated receptor gamma2. J Biol Chem 280: 14656-62 [PMID:15710620]

112. Southern C, Cook JM, Neetoo-Isseljee Z, Taylor DL, Kettleborough CA, Merritt A, Bassoni DL, Raab WJ, Quinn E and Wehrman TS et al.. (2013) Screening $\beta$-Arrestin Recruitment for the Identification of Natural Ligands for Orphan G-Protein-Coupled Receptors. J Biomol Screen 18: 599-609 [PMID:23396314]

113. Sumida H, Noguchi K, Kihara Y, Abe M, Yanagida K, Hamano F, Sato S, Tamaki K, Morishita Y and Kano MR et al.. (2010) LPA4 regulates blood and lymphatic vessel formation during mouse embryogenesis. Blood 116: 5060-70 [PMID:20713964]

114. Swaney JS, Chapman C, Correa LD, Stebbins KJ, Broadhead AR, Bain G, Santini AM, Darlington J, King CD and Baccei CS et al.. (2011) Pharmacokinetic and pharmacodynamic characterization of an oral lysophosphatidic acid type 1 receptor-selective antagonist. J Pharmacol Exp Ther 336 : 693-700 [PMID:21159750]

115. Swaney JS, Chapman C, Correa LD, Stebbins KJ, Bundey RA, Prodanovich PC, Fagan P, Baccei CS, Santini AM and Hutchinson JH et al.. (2010) A novel, orally active LPA(1) receptor antagonist inhibits lung fibrosis in the mouse bleomycin model. Br J Pharmacol 160: 1699-713 [PMID:20649573]

116. Taniguchi R, Inoue A, Sayama M, Uwamizu A, Yamashita K, Hirata K, Yoshida M, Tanaka Y, Kato HE and Nakada-Nakura Y et al.. (2017) Structural insights into ligand recognition by the lysophosphatidic acid receptor LPA $_{6}$. Nature 548: 356-360 [PMID:28792932]

117. Tariq M, Ayub M, Jelani M, Basit S, Naz G, Wasif N, Raza SI, Naveed AK, ullah Khan S and Azeem Z et al.. (2009) Mutations in the P2RY5 gene underlie autosomal recessive hypotrichosis 
in 13 Pakistani families. Br J Dermatol 160: 1006-10 [PMID:19292720]

118. Terakado M, Suzuki H, Hashimura K, Tanaka M, Ueda H, Kohno H, Fujimoto T, Saga H, Nakade $\mathrm{S}$ and Habashita $\mathrm{H}$ et al.. (2016) Discovery of ONO-7300243 from a Novel Class of Lysophosphatidic Acid Receptor 1 Antagonists: From Hit to Lead. ACS Med Chem Lett 7: 913918 [PMID:27774128]

119. Virag T, Elrod DB, Liliom K, Sardar VM, Parrill AL, Yokoyama K, Durgam G, Deng W, Miller DD and Tigyi G. (2003) Fatty alcohol phosphates are subtype-selective agonists and antagonists of lysophosphatidic acid receptors. Mol Pharmacol 63: 1032-42 [PMID:12695531]

120. von Kügelgen I. (2006) Pharmacological profiles of cloned mammalian P2Y-receptor subtypes. Pharmacol Ther 110: 415-32 [PMID:16257449]

121. Webb TE, Kaplan MG and Barnard EA. (1996) Identification of 6H1 as a P2Y purinoceptor: P2Y5. Biochem Biophys Res Commun 219: 105-10 [PMID:8619790]

122. Weiner JA and Chun J. (1999) Schwann cell survival mediated by the signaling phospholipid lysophosphatidic acid. Proc Natl Acad Sci USA 96: 5233-8 [PMID:10220449]

123. Weiner JA, Fukushima N, Contos JJ, Scherer SS and Chun J. (2001) Regulation of Schwann cell morphology and adhesion by receptor-mediated lysophosphatidic acid signaling. J Neurosci $\mathbf{2 1}$ : 7069-78 [PMID:11549717]

124. Williams JR, Khandoga AL, Goyal P, Fells JI, Perygin DH, Siess W, Parrill AL, Tigyi G and Fujiwara Y. (2009) Unique ligand selectivity of the GPR92/LPA5 lysophosphatidate receptor indicates role in human platelet activation. J Biol Chem 284: 17304-19 [PMID:19366702]

125. Xu Y, Aoki J, Shimizu K, Umezu-Goto M, Hama K, Takanezawa Y, Yu S, Mills GB, Arai H and Qian L et al.. (2005) Structure-activity relationships of fluorinated lysophosphatidic acid analogues. J Med Chem 48: 3319-27 [PMID:15857137]

126. Yanagida K, Igarashi H, Yasuda D, Kobayashi D, Ohto-Nakanishi T, Akahoshi N, Sekiba A, Toyoda T, Ishijima T and Nakai Y et al.. (2018) The Go12/13-coupled receptor LPA4 limits proper adipose tissue expansion and remodeling in diet-induced obesity. JCI Insight 3 [PMID:30568036]

127. Yanagida K, Ishii S, Hamano F, Noguchi K and Shimizu T. (2007) LPA4/p2y9/GPR23 mediates rho-dependent morphological changes in a rat neuronal cell line. J Biol Chem 282: 5814-24 [PMID:17172642]

128. Yanagida K, Masago K, Nakanishi H, Kihara Y, Hamano F, Tajima Y, Taguchi R, Shimizu T and Ishii S. (2009) Identification and characterization of a novel lysophosphatidic acid receptor, p2y5/LPA6. J Biol Chem 284: 17731-41 [PMID:19386608]

129. Yanagida K and Valentine WJ. (2020) Druggable Lysophospholipid Signaling Pathways. Adv Exp Med Biol 1274: 137-176 [PMID:32894510]

130. Yang AH, Ishii I and Chun J. (2002) In vivo roles of lysophospholipid receptors revealed by gene targeting studies in mice. Biochim Biophys Acta 1582: 197-203 [PMID:12069829]

131. Yasuda D, Kobayashi D, Akahoshi N, Ohto-Nakanishi T, Yoshioka K, Takuwa Y, Mizuno S, Takahashi S and Ishii S. (2019) Lysophosphatidic acid-induced YAP/TAZ activation promotes developmental angiogenesis by repressing Notch ligand Dll4. J Clin Invest 129: 4332-4349 [PMID:31335323]

132. Ye X, Hama K, Contos JJ, Anliker B, Inoue A, Skinner MK, Suzuki H, Amano T, Kennedy G and Arai $\mathrm{H}$ et al.. (2005) LPA3-mediated lysophosphatidic acid signalling in embryo implantation and spacing. Nature 435: 104-8 [PMID:15875025]

133. Ye X, Skinner MK, Kennedy G and Chun J. (2008) Age-dependent loss of sperm production in mice via impaired lysophosphatidic acid signaling. Biol Reprod 79: 328-36 [PMID:18448840]

134. Yukiura H, Kano K, Kise R, Inoue A and Aoki J. (2015) LPP3 localizes LPA6 signalling to noncontact sites in endothelial cells. J Cell Sci 128: 3871-7 [PMID:26345369]

135. Yung YC, Mutoh T, Lin ME, Noguchi K, Rivera RR, Choi JW, Kingsbury MA and Chun J. (2011) Lysophosphatidic acid signaling may initiate fetal hydrocephalus. Sci Transl Med 3: 99ra87 [PMID:21900594]

136. Yung YC, Stoddard NC and Chun J. (2014) LPA receptor signaling: pharmacology, physiology, and pathophysiology. J Lipid Res 55: 1192-1214 [PMID:24643338]

137. Zhang H, Xu X, Gajewiak J, Tsukahara R, Fujiwara Y, Liu J, Fells JI, Perygin D, Parrill AL and Tigyi G et al.. (2009) Dual activity lysophosphatidic acid receptor pan-antagonist/autotaxin inhibitor reduces breast cancer cell migration in vitro and causes tumor regression in vivo. Cancer Res 69: 5441-9 [PMID:19509223] 